developed by scientists for the pre-trial investigation of criminal offenses at each stage of the formation of their professional consciousness.

Recommendations of a technical nature allow the most effective use of forensic techniques to detect, record and study the reflections that the offender leaves in the external environment. Tactical recommendations allow the investigator to conduct investigative (search) actions in the most tactful way in order to obtain new and verify already obtained evidence in criminal proceedings. Forensic recommendations of a methodological nature allow to choose the right strategy of investigation, to determine the order and priority of investigative (search) actions and organizational measures, etc. Finally, it should be noted that such recommendations are of particular value provided they are comprehensive and logically structured.

Thus, the availability of professionally developed and practically oriented forensic recommendations for pre-trial investigation is one of the necessary conditions for ensuring the effectiveness of pre-trial investigation and access of individuals to fast and efficient justice in criminal proceedings.

DOI https://doi.org/10.30525/978-9934-588-92-1-89

\title{
ДО ПИТАННЯ ВИЗНАЧЕННЯ ПОНЯТТЯ ЕФЕКТИВНОСТІ ДОСУДОВОГО РОЗСЛІДУВАННЯ
}

\author{
Корчева Т. В. \\ кандидат юридичних наук, \\ асистент кафедри кримінального процесу \\ Національного юридичного університету імені Ярослава Мудрого \\ м. Харків, Україна
}

Кримінальний процесуальний кодекс України (далі КПК України) у ст.ст. 36, 38-40 закріплює одним з обов'язків суб'єктів, які ведуть досудове розслідування (прокурора, керівника органу досудового розслідування, слідчого) забезпечення ефективності досудового розслідування [1]. Але, у КПК України визначення терміна «ефективність», що вживається на позначення обов'язку у процесуальної діяльності вищевказаних суб'єктів, відсутнє. Разом із тим, варто зазначити, що невиконання вказаного обов'язку тягне певні процесуальні наслідки. Так, керівником органу прокуратури, через неефективне здійснення прокурором нагляду за дотриманням законів 
під час проведення досудового розслідування, у виняткових випадках, повноваження прокурора можуть бути покладені на іншого прокурора цього органу прокуратури (ч. 3 ст. 37 КПК). У свою чергу, прокурор, який здійснює нагляд у формі процесуального керівництва за додержанням законів під час проведення досудового розслідування, відповідно до п. 8 ч. 2 ст. 36 КПК України наділений повноваженням ініціювати перед керівником органу досудового розслідування питання про відсторонення слідчого від проведення досудового розслідування у випадку неефективного досудового розслідування. Це положення узгоджується 3 обов'язком органу досудового розслідування, закріпленим у ч. 4 ст. 38 КПК України, вжити всіх передбачених законом заходів для забезпечення ефективності досудового розслідування, а його керівник, виконуючи приписи п. 2 ч. 2 ст. 39 КПК України, за ініціативою прокурора або з власної ініціативи з наступним повідомленням прокурора у змозі за вмотивованою постановою у разі неефективного досудового розслідування відсторонювати слідчого від проведення досудового розслідування.

Приписи відомчих нормативних актів, зокрема, Положення про слідчі підрозділи Національної поліції України та Інструкція 3 організації діяльності слідчих підрозділів Національної поліції України, затверджені наказом Міністерства внутрішніх справ України від 06.07.2017p. № 570 «Про організацію діяльності слідчих підрозділів Національної поліції України» визначають завдання органів досудового розслідування із забезпеченням ефективності досудового розслідування [2].

Для розуміння поняття ефективності досудового розслідування варто звернутися до Порядку організації діяльності прокурорів i слідчих органів прокуратури у кримінальному провадженні, затвердженому наказом Генеральної прокуратури України від 28.03.2019 р. № 51, який визначає критерії, які ураховуються при вирішенні питання про відсторонення слідчого від проведення досудового розслідування у разі неефективного досудового розслідування: не забезпечено виконання завдань кримінального провадження; порушено загальні засади кримінального провадження, що негативно вплинуло або може вплинути на обгрунтованість, всебічність і повноту у кримінальному провадженні; низька якість процесуальної діяльності слідчого (слідчої групи), унаслідок чого отримані результати такої діяльності не відповідають обгрунтовано допустимим результатам, які повинні були й об'єктивно могли бути досягнуті за цей час з огляду на складність $\mathrm{i}$ специфіку розслідування кримінального правопорушення [3]. Проектом Закону України «Про внесення змін до Закону України «Про прокуратуру» щодо підвищення ефективності діяльності органів 356 
прокуратури» від 13.02.2020 р. № 3062 (внесли народні депутати України В. Неклюдов, В. А. Медяник, Г. Михайлюк, С. Іонушас, М. В. Павлюк, А. Дмитрук, Г. Мамка, Ю. Яцик, О. Бакумов, О. Дануца, В. Захарченко, С. Алєксєєв, В. Арешонков) пропонується у нової редакції ч. 2 ст. 25 передбачити, що Генеральний прокурор, керівники відповідних прокуратур, їх перші заступники та заступники відповідно до розподілу обов'язків координують діяльність правоохоронних органів відповідного рівня у сфері протидії злочинності. Основною формою координації $\epsilon$ проведення координаційних нарад, на яких заслуховується інформація щодо діяльності у сфері протидії злочинності. Рішення координаційної наради $€$ обов'язковим до виконання всіма зазначеними в ньому правоохоронними органами [4].

Конституційний Суд України у рішенні від 24 квітня 2018 року № 3-p/2018 р. у справі за конституційним поданням Уповноваженого Верховної Ради України з прав людини щодо відповідності Конституції України (конституційності) частини шостої статті 216 Кримінального процесуального кодексу України (Справа № 1-22/2018(762/17) вважає, що позитивний обов'язок держави стосовно впровадження належної системи захисту життя, здоров'я та гідності людини передбачає забезпечення ефективного розслідування, яке вимірюється його повнотою, всебічністю, оперативністю, незалежністю [5].

Певний інтерес викликає практика Європейського суду з прав людини (далі - ЄСПЛ), у рішеннях якого розглядаються критерії ефективності. Так, у своїх рішеннях ЄСПЛ визнає, що обов'язком національних органів $\epsilon$ проведення ефективного офіційного розслідування (справа «Алексахін проти України» від 19.07.2012р.); Суд повторює, що обов'язок охороняти право на життя за статтею 2 Конвенції, за своїм змістом вимагає проведення ефективного офіційного розслідування, головна мета такого розслідування полягає у забезпеченні ефективного виконання положень національного законодавства, яке охороняє право на життя. (справа «Холодков і Холодкова проти України» від 7.05.2015 р.) [6; ]; Для того, щоб розслідування могло вважатися ефективним, воно має привести до встановлення і покарання винних осіб (справа «Чумак проти України» від 06.03.2018 р.) [8]; Розслідування має бути ретельним, незалежним, безстороннім і підконтрольним громадськості, а також те, що компетентні органи влади повинні діяти зі зразковою ретельністю й оперативністю (справа «Бєлоусов проти України» від 07.02.2014p.) [9]; Ефективність розслідування втілюе в собі вимоги щодо оперативності та розумної швидкості. Навіть якщо існують перешкоди або труднощі, які перешкоджають прогресу розслідування у конкретній ситуації, оперативне реагування національних органів влади є надзвичайно важливим для 
підтримання громадської віри в їх відданість принципам верховенства права (справа «Риженко проти України» від 30.07.2015 р.) [10].

Отже, на нашу думку, склалася достатньо велика база у вітчизняному українському законодавстві щодо визначення поняття ефективності досудового розслідування, низка рішень ЄСПЛ щодо розуміння ефективності розслідування. Виходячи зі сказаного, вважаємо за доцільне: 1) визначити поняття «ефективність досудового розслідування», яке закріпити у ч. 1 ст. 3 КПК України наступним текстом: «Ефективність досудового розслідування - це обов'язок суб'єктів, які провадять кримінальне провадження на стадії досудового розслідування по вирішенню завдань кримінального провадження, забезпечення всебічності, повноти i неупередженості дослідження обставин кримінального провадження, у розумні строки, 3 дотриманням засад кримінального провадження, а також пріоритетності прав і свобод людини»; 2) внести доповнення до ст. 36, ст. 39, ст. 40, додавши вказівку про обов'язок відповідних суб'єктів забезпечувати ефективність досудового розслідування.

\section{Література:}

1. Кримінальний процесуальний кодекс України: Закон України від 13.04.2012 p. № 4651-VI. Дата оновлення: 11.09.2020 p. URL: https://zakon.rada.gov.ua/laws/show/4651-17\#Text. (дата звернення 19.10.2020).

2. Про організацію діяльності слідчих підрозділів Національної поліції України: затв. наказом М-ва внутрішніх справ України від 06.07.2017 p. № 570. Дата оновлення 17.07.2020p. URL: https://zakon.rada.gov.ua/laws/show/z0918-17\#Text. (дата звернення 17.10.2020).

3. Порядок організації діяльності прокурорів і слідчих органів прокуратури у кримінальному провадженні: затв. наказом Генеральної прокуратури України від 28.03.2019 p. № 51. URL: https://ips.ligazakon.net/document/view/RE33334?an=1. (дата звернення 18.10.2020).

4. Про внесення змін до Закону України «Про прокуратуру» щодо підвищення ефективності діяльності органів прокуратури: проект Закону України від 13.02.2020 p. № 3062. URL: http://w1.c1.rada.gov.ua/ pls/zweb2/webproc6_current_main?id=\&pid069=242. (дата звернення 20.10.2020).

5. Рішення Конституційного Суду України від 24 квітня 2018 року № 3-p/2018p. у справі за конституційним поданням Уповноваженого Верховної Ради України з прав людини щодо відповідності Конституції 358 
України (конституційності) частини шостої статті 216 Кримінального процесуального кодексу України (Справа № 1-22/2018(762/17). URL: http://search.ligazakon.ua/__doc2.nsf/link1/KS18075.html. (дата звернення 18.10.2020).

6. Рішення Європейського суду з прав людини у справі «Алексахін проти України» (заява № 31939/06). Прийняття 19.07.2012p. (остаточне 19.10.12p.). URL: https://zakon.rada.gov.ua/laws/show/974_925. (дата звернення 16.10.2020).

7. Рішення Свропейського суду з прав людини у справі «Холодков і Холодкова проти України» (заява № 29697/08) від 7.05.2015 р.) URL: https://zakon.rada.gov.ua/laws/show/974_a66\#Text. (дата звернення 21.10.2020).

8. Рішення Європейського суду з прав людини у справі «Чумак проти України» (заява № 44529/09). Прийняття 06.03.2018р. (остаточне 06.06.2018p.). URL: https://zakon.rada.gov.ua/laws/show/974_e02\#Text. (дата звернення 17.10.2020).

9. Рішення Свропейського суду з прав людини у справі «Бєлоусов проти України» (заява № 4494/07). Прийняття 07.11.2013p. (остаточне 07.02.2014p.). URL: https://zakon.rada.gov.ua/laws/show/en/974_989. (дата звернення 18.10.2020).

10. Рішення Європейського суду з прав людини у справі «Риженко проти України» (заява № 55902/11). Прийняття 30.07.2015p. URL: https://zakon.rada.gov.ua/laws/show/974_a73\#Text. (дата звернення 17.10.2020). 